\title{
Potensi Jus Buah Naga Merah (Hylocereus polyrhizus) terhadap Perbaikan Jaringan Organ Otak Tikus (Rattus norvegicus) Diabetes
}

\author{
I Gede Gelgel Bayu Surya Putra ${ }^{1}$, Dorta Simamora ${ }^{2}$ \\ Rumah Sakit Bangli, Provinsi Bali ${ }^{1}$ \\ Biomedik Fakultas Kedokteran Universitas Wijaya Kusuma Surabaya2* \\ *e-mail: dortasimamora@gmail.com
}

\begin{abstract}
Abstrak
Diabetes mellitus adalah penyakit metabolik yang ditandai dengan hiperglikemia akibat gangguan pada sekresi insulin, kerja insulin, atau keduanya. Tujuan dari penelitian ini adalah untuk menganalisis pengaruh pemberian jus buah naga merah (Hylocereus polyrhizus) terhadap perbaikan Histopatologis organ otak tikus wistar betina (Rattus norvergicus strain wistar) dengan diabetes. Jenis penelitian yang digunakan pada penelitian ini adalah true experimental dengan desain randomized control-group pretest-postest yang dilakukan di Laboratorium in Vivo Universitas Wijaya Kusuma Surabaya. Dua puluh lima ekor tikus wistar betina dibagi secara acak menjadi 5 kelompok yaitu, kelompok tikus normal KA (tanpa induksi aloksan), kelompok tikus diabetes KB (induksi aloksan tanpa pemberian jus buah naga merah), kelompok KC (induksi aloksan + jus buah naga merah $2 \mathrm{gr} / 2,5 \mathrm{ml}$ ), kelompok KD (induksi aloksan + jus buah naga merah $4 \mathrm{gr} / 2,5 \mathrm{ml}$ ) dan kelompok KE (induksi Aloksan + jus buah naga merah $8 \mathrm{gr} / 2,5 \mathrm{ml}$ ). Penelitian dilakukan selama 16 hari dengan sebelumnya dilakukan adaptasi pakan standar selama 7 hari. Pada hari ke 16 tikus diterminasi. Pengukuran kadar gula darah tikus dilakukan dengan glukosa meter. Pengamatan histopatologis jaringan otak tikus menggunakan mikroskop Olympus CX21 dengan pewarnaan Haematoksilin Eosin (HE). Hasil penelitian menunjukkan bahwa pemberian jus buah naga merah terbaik pada kadar gula darah tikus dibanding antara KB dan KE dengan signifikan $p$-value $=0,000(\alpha<0,05)$. Penurunan kadar gula darah pada tikus diabetes secara signifikan antara KB dan KE juga tampak terjadi penurunan jaringan otak tikus yang mengalami nekrosis $p$-value $=0,000$ berarti $\alpha<0,05$.
\end{abstract}

Kata Kunci: diabetes mellitus, jus buah naga merah, kadar glukosa, nekrosis otak

\section{Potential of Red Dragon Fruit Juices (Hylocereus polyrhizus) to the Brain Histopathologic Repair in Rats (Rattus norvegicus) with Diabetes}

\begin{abstract}
Diabetes mellitus is a metabolic disease characterized by hyperglycemia due to disturbances in insulin secretion, insulin action, or both. The purpose of this study was to analyze the effect of the red dragon fruit juice (Hylocereus polyrhizus) to repair brain organ histopathologic female wistar rats (Rattus norvegicus Wistar strain) with diabetes. This research is a true experiment research with randomized control - group pretest - posttest design and were conducted at the in Vivo Laboratory of Wijaya Kusuma University Surabaya. Twenty-five female wistar rats were randomly divided into 5 groups, normal rats group KA (without alloxan induction), diabetic rats group $K B$ (alloxan induction and without given any red dragon fruit juices), treatment group KC (alloxan induction $+2 \mathrm{gr} / 2,5 \mathrm{ml}$ of red dragon fruit juices), treatment group KD (alloxan induction $+4 \mathrm{gr} / 2,5 \mathrm{ml}$ of red dragon fruit juices) and treatment group KE (alloxan induction +8
\end{abstract}


Potensi Jus Buah Naga Merah (Hylocereus polyrhizus) terhadap Perbaikan Jaringan Organ...

I Gede Gelgel Bayu Surya Putra, Dorta Simamora

$\mathrm{gr} / 2,5 \mathrm{ml}$ of red dragon fruit juices). The study was conducted during the period of 16 days with standard feeding adaptations for 7 days. On day $16^{\text {th }}$, all the rats were terminated. Glucose meter is used to measure the levels of blood glucose in rats. Histopathologic observation of rat brain tissue using a microscope Olympus CX21 with Haematoksilin eosin (HE) staining. The results showed the best dose of red dragon fruit juices to decrease blood glucose levels compare between $K B$ and $K E$ with significance $p$-value $=0.000(\alpha<0.05)$, the blood glucose levels decreased in diabetic rats significantly between $K B$ and KE also decreased in rat brain tissue necrosis with $p$-value $=0.000(\alpha<0.05)$.

Keyword: diabetes mellitus, red dragon fruit, glucose level, brain Necrosis

\section{PENDAHULUAN}

Diabetes mellitus (DM) dikenal sebagai silent killer karena sering tidak disadari oleh penyandangnya dan saat diketahui sudah terjadi komplikasi (Infodatin, 2018). DM juga merupakan penyakit kronis yang kompleks akibat gangguan metabolisme glukosa yang disebabkan kekurangan insulin baik secara absolut maupun relatif atau peningkatan kadar glukosa darah di atas nilai normal, keadaan ini mengakibatkan hiperglikemia serta gangguan metabolisme karbohidrat, lemak, dan protein (American Diabetes Association, 2018; Diabetes Care, 2018)

Menurut Profil Kesehatan Indonesia tahun 2013, prevalensi diabetes di Indonesia berdasarkan wawancara adalah $2,1 \%$. Angka tersebut lebih tinggi dibanding dengan tahun 2007 (1,1\%). Sebanyak 31 provinsi $(93,9 \%)$ menunjukkan kenaikan prevalensi DM (Kemenkes, 2014).

Buah naga merah kaya dengan antioksidan. Di dalamnya terkandung berbagai zat yang baik bagi tubuh seperti: kalsium, betakaroten, vitamin, B1, vitamin B2, vitamin C, fosfor dan zat flavonoid (Kristanto, 2008). Flavonoid termasuk dalam golongan senyawa phenolik. Flavonoid berperan sebagai antioksidan dengan cara mendonasikan atom hidrogennya atau melalui kemampuannya mengkelat logam, berada dalam bentuk glukosida (mengandung rantai samping glukosa) atau dalam bentuk bebas yang disebut aglikon (Heim et al, 2002; Huang, 2018).

Diabetes mellitus menyebabkan komplikasi dalam tubuh karena kelebihan gula dalam darah, sehingga dapat merusak jaringan dan organ lain. Pada otak, dengan diabetes dikaitkan dengan disfungsi kognitif dan peningkatan risiko demensia. Studi pada orang dewasa dengan diabetes tipe 1 menunjukkan penurunan volume otak. Pada mereka dengan onset diabetes dimasa kecil, pengurangan volume mencerminkan jumlah perubahan yang terjadi selama perkembangan otak dan perubahan yang terjadi di kemudian hari 
ISSN 1978-2071 (Print); ISSN 2580-5967 (Online) Jurnal IImiah Kedokteran Wijaya Kusuma 8(2) : 84-95, September 2019

karena paparan faktor yang berhubungan dengan diabetes. Diabetes tipe 2 berhubungan dengan atrofi otak dan penyakit pembuluh darah kecil. Perubahan otak ini terjadi pada usia lanjut dalam kaitannya dengan faktor risiko vaskular yang merugikan (Biessels and Reijmer, 2014).

\section{BAHAN DAN METODE}

Dua puluh lima ekor tikus wistar betina dibagi secara acak menjadi 5 kelompok yaitu, kelompok:

KA (tanpa induksi aloksan), kelompok normal

KB (induksi aloksan tanpa pemberian jus buah naga merah), kelompok tikus diabetes

KC (induksi aloksan + jus buah naga merah $2 \mathrm{gr} / 2,5 \mathrm{ml}$ ),

KD (induksi aloksan + jus buah naga merah $4 \mathrm{gr} / 2,5 \mathrm{ml})$

KE (induksi Aloksan + jus buah naga merah $8 \mathrm{gr} / 2,5 \mathrm{ml})$.

Penelitian dilakukan selama 16 hari dengan diadaptasikan terlebih dahulu, diberi pakan standar selama 7 hari. Pada hari ke 16 tikus diterminasi. Pengukuran kadar gula darah tikus dilakukan dengan glukosa meter. Pengamatan histopatologis jaringan otak tikus menggunakan mikroskop Olympus CX21 dengan pewarnaan Haematoksilin Eosin (HE).

\section{HASIL PENELITIAN}

Berdasarkan hasil penelitian diperoleh kadar gula darah tikus dan jumlah nekrosis jaringan otak tikus sebelum dan setelah perlakuan (Tabel) dapat kita lihat jumlah rata-rata nekrosis jaringan otak tikus pada kelompok tikus normal (KA) adalah kelompok tanpa induksi aloksan, sebanyak 4,4 sel. Jumlah rata-rata nekrosis jaringan otak tikus paling banyak terdapat pada kelompok tikus diabetes (KB) yang diinduksi aloksan tanpa diberi jus buah naga merah dengan rata-rata sebesar 27,6 sel. Sedangkan pada kelompok tikus (KC) diinduksi aloksan dan diberi jus buah naga merah sebanyak $2 \mathrm{gr} / 2.5 \mathrm{ml}$ jumlah rata-rata nekrosis jaringan otak tikus sebanyak 21,4 sel. Kelompok (KD) kelompok yang diinduksi aloksan dan diberi jus buah naga merah sebanyak $4 \mathrm{gr} / 2.5 \mathrm{ml}$, jumlah rata-rata nekrosis jaringan otak tikus sebanyak 18 sel. Pada kelompok (KE) adalah diinduksi aloksan dan diberi jus buah naga merah sebanyak $8 \mathrm{gr} / 2.5 \mathrm{ml}$ jumlah rata-rata nekrosis jaringan otak tikus sebanyak 10,2 sel. Jumlah rata-rata nekrosis jaringan otak tikus yang diberikan jus buah naga merah lebih kecil jika dibandingkan dengan kelompok tikus diabetes (KB). Jumlah rata-rata nekrosis jaringan otak tikus yang paling mendekati rata-rata nekrosis jaringan otak tikus normal (KA) adalah kelompok tikus KE yang 
Potensi Jus Buah Naga Merah (Hylocereus polyrhizus) terhadap Perbaikan Jaringan Organ... I Gede Gelgel Bayu Surya Putra, Dorta Simamora

diberikan jus buah naga merah dosis III (8 gram/ 2,5 ml).

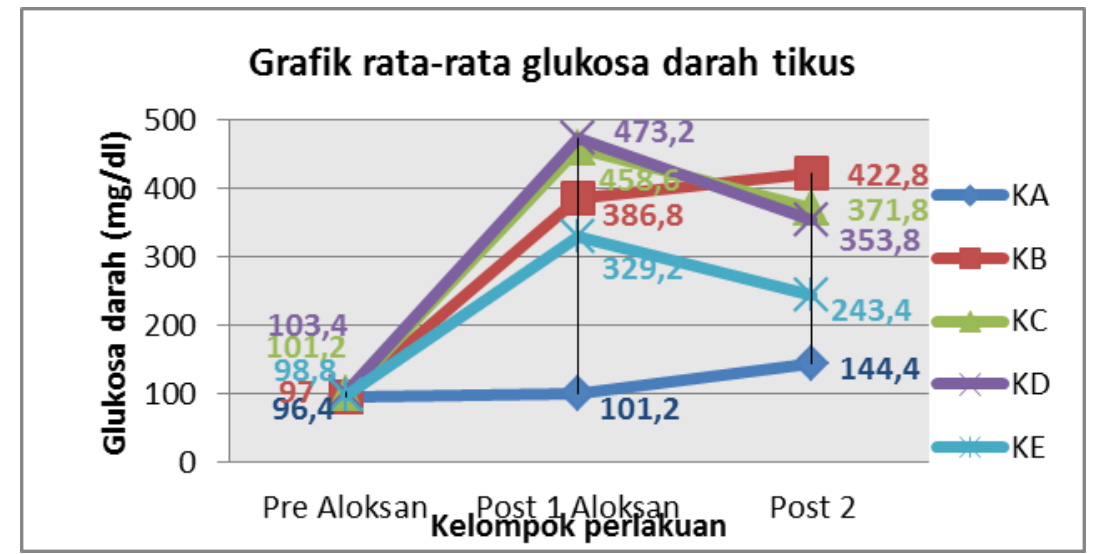

Gambar 1. Rata-rata kadar glukosa darah tikus sebelum dan setelah perlakuan

Pada Kelompok KC terlihat adanya peningkatan kadar gula darah gula darah tikus setelah injeksi aloksan (post 1) dan terlihat menurun pada pengecekan kadar gula darah akhir (post 2), namun masih diatas 250 mg/dl. Pada Kelompok KD kadar gula darah tikus tertinggi terukur pada pengecekan setelah injeksi aloksan (post 1) dan terlihat menurun pada pengecekan kadar gula darah akhir (post 2), namun masih diatas $250 \mathrm{mg} / \mathrm{dl}$. Pada kelompok KE terlihat adanya lonjakan peningkatan kadar gula darah tikus setelah dilakukannya injeksi aloksan (post 1), namun kadar gula darah rata-rata terlihat menurun pada pengecekan akhir (post 2) dengan kadar rata-rata dibawah $250 \mathrm{mg} / \mathrm{dl}$.

Berdasarkan Gambar 1 dapat diketahui bahwa rata-rata gula darah tikus tertinggi ada pada kelompok tikus diabetes KB (tanpa terapi jus buah naga merah) yaitu sebesar $422,8 \mathrm{mg} / \mathrm{dl}$ dan rata-rata terendah terdapat pada kelompok tikus normal (KA) yaitu sebesar 144,4 mg/dl. Pada kelompok perlakuan yang diberi jus buah naga merah rata-rata gula darah tikus terendah terdapat pada kelompok KE yaitu sebesar $243,4 \mathrm{mg} / \mathrm{dl}$.

Hasil pengamatan penghitungan jumlah nekrosis jaringan otak pada tikus diabetes yang diinduksi aloksan dapat dilihat pada Gambar 2.

Nekrosis Pada Otak Tikus dengan Diabetes

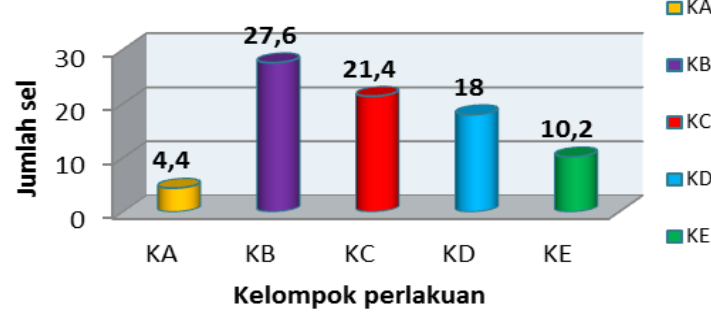

Gambar 2. Hasil pengamatan penghitungan nekrosis otak tikus

Berdasarkan Gambar 2 dapat diketahui bahwa rata-rata nekrosis otak tertinggi ada pada kelompok tikus diabetes KB (tanpa terapi jus buah naga merah) yaitu sebesar 27,6 sel dan rata-rata 
ISSN 1978-2071 (Print); ISSN 2580-5967 (Online) Jurnal IImiah Kedokteran Wijaya Kusuma 8(2) : 84-95, September 2019

terendah ada pada kelompok tikus normal

(KA) yaitu sebesar 4,4 sel. Pada kelompok perlakuan yang diberikan jus buah naga merah rata-rata nekrosis otak terendah
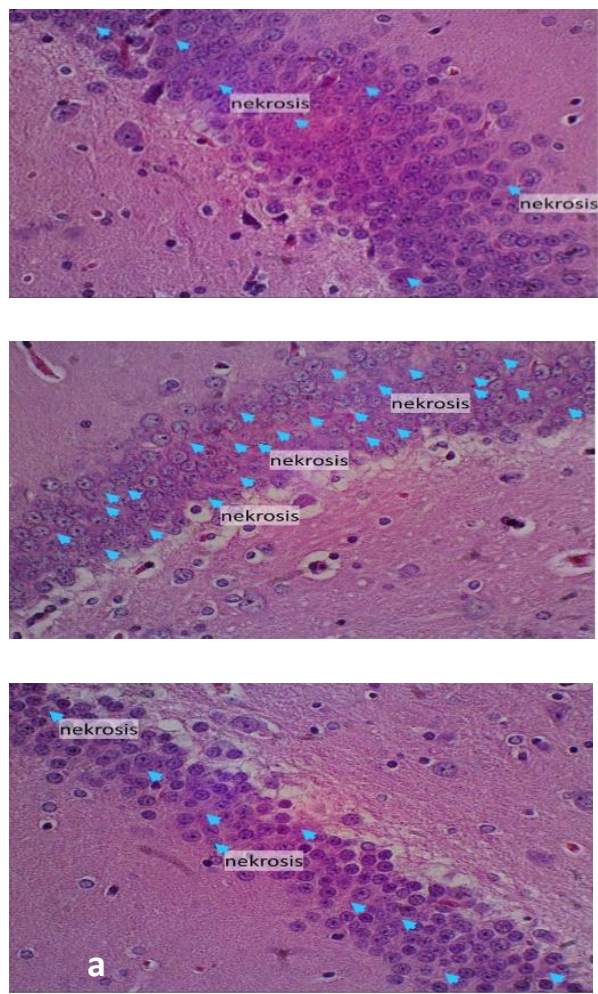

Gambar 3. Gambaran histopatologis nekrosis jaringan otak tikus dengan diabetes (perbesaran 400x)

Sel nekrosis ditunjukkan dengan panah (

(a) Jaringan otak tikus normal (KA3) tanpa induksi aloksan dan jus buah naga merah, jumlah nekrosis 7 sel.

(b) Jaringan otak tikus diabetes (KB4) diinduksi aloksan tanpa pemberian jus buah naga merah, jumlah nekrosis 28 sel.

(c) Jaringan otak tikus KC5 diinduksi aloksan dan diberikan jus buah naga merah dosis I, jumlah nekrosis 25 sel.

(d) Jaringan otak tikus KD2 diinduksi aloksan dan diberikan jus buah naga merah dosis II, jumlah nekrosis 16 sel. terdapat pada kelompok tikus KE. Gambaran nekrosis pada jaringan otak tikus dapat dilihat pada Gambar 3.
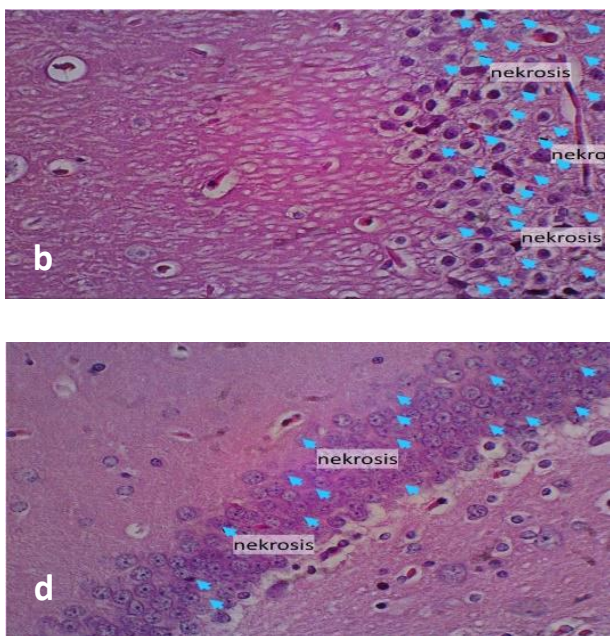

(e) Jaringan otak tikus KE3 diinduksi aloksan dan diberikan jus buah naga merah dosis III, jumlah nekrosis 9 sel.

Pengaruh kadar gula darah tikus dengan kejadian nekrosis pada jaringan otak tikus betina dengan diabetes.

Berdasarkan Gambar 2 terlihat bahwa kadar gula darah tikus dari kelompok yang diberi perlakuan yang mendekati dengan kelompok tikus normal (KA) adalah kelompok tikus KE. Pada kelompok tikus KE (dosis $8 \mathrm{gr} / 2,5 \mathrm{ml} 1$ kali 
Potensi Jus Buah Naga Merah (Hylocereus polyrhizus) terhadap Perbaikan Jaringan Organ...

I Gede Gelgel Bayu Surya Putra, Dorta Simamora

sehari) terjadi penurunan kadar gula darah terbaik, dengan rata-rata $243,4 \mathrm{mg} / \mathrm{dl}$. Tampak dalam gambar (grafik) bahwa baik pada pengukuran kadar gula darah tikus maupun pengamatan pada nekrosis jaringan otak tikus menunjukkan penurunan gula darah tikus memberikan pengaruh positif terhadap penurunan dari terjadinya nekrosis pada jaringan otak tikus dengan rata-rata 10,2 sel. Pada kelompok tikus normal (KA) dibandingkan dengan kelompok tikus KE dimana kadar gula darah tikus yang turun diikuti dengan penurunan terjadinya nekrosis pada jaringan otak tikus secara signifikan dimana $p$-value $=0.008$ yaitu $\alpha<0,05$. Kadar gula darah pada kelompok tikus KC dan KD mengalami penurunan tetapi tidak begitu berarti, dengan kata lain tidak ada perbedaan antar perlakuan, dimana $p$-value $=0.595$ yaitu $\alpha>$ 0,05 . Demikian juga pada nekrosis jaringan otak tikus diabetes baik KC dan KD telah ada perbedaan antar perlakuan, dimana $p$ value $=0,182$ yaitu $\alpha>0,05$.

\section{PEMBAHASAN}

Potensi pemberian jus buah naga merah terhadap kadar glukosa darah dan dengan kejadian nekrosis pada jaringan otak tikus diabetes.

Melalui hasil penelitian menunjukkan bahwa, penurunan kadar glukosa darah (Gambar 1.) pada tikus dari semua kelompok perlakuan (KC, KD, dan KE) diikuti dengan perbaikan jaringan otak yang ditandai dengan penurunan jumlah jaringan otak yang mengalami nekrosis (Gambar 2.). Rata rata jumlah jaringan otak yang mengalami nekrosis terendah terdapat pada kelompok KE, begitu juga dengan rata rata pada penurunan kadar glukosa darah tikus diabetes.

Kenaikan kadar glukosa darah dari kelompok tikus diabetes (KB), KC, $K D$, dan KE pada post 1 merupakan akibat pemberian suntikan aloksan secara intraperitoneal. Aloksan secara selektif merusak sel beta dari pulau Langerhans pankreas yang mensekresi hormon insulin. Mekanisme ini melalui dua cara yakni ganguan homeostatis $\mathrm{Ca}$ dan aktivitas radikal bebas yang terbentuk melalui siklus oksidasi reduksi antara aloksan dan glutation (Szkudelski, 2001). Pengukuran kadar glukosa darah tikus Post 2 terlihat adanya penurunan kadar glukosa darah dibandingkan kadar glukosa setelah penginduksian aloksan (post 1). Hasil pengamatan yang dilakukan berdasarkan uji One Way Anova dengan hasil analisis yang telah diolah dengan Program Statistical Product and Service Solution (SPSS) versi 16.0 
menunjukkan signifikansi $p$-value $=$ $0.000(<\alpha=0.05)$ maka ada pengaruh antara pemberian jus buah naga merah terhadap penurunan kadar gula darah tikus diabetes yang diinduksi aloksan.

\section{Hubungan antara kadar glukosa darah dan nekrosis pada tikus diabetes dengan flavonoid yang terdapat pada jus buah naga merah.}

Efek hipoglikemik dari buah naga merah ini sesuai dengan hasil penelitian dari Feranose (2009) dimana dalam penelitiannya Pemberian jus buah naga merah dapat menurunkan kadar glukosa darah tikus putih yang diinduksi aloksan sebanding dengan efek yang ditimbulkan oleh glibenklamid. Zat fenolik flavonoid, berfungsi sebagai peredam radikal bebas yang ampuh, terutama pada diabetes mellitus. Efek protektif flavonoid dalam sistem biologis memiliki kapasitas untuk memindahkan hidrogen atau elektron radikal bebas, mengaktifkan enzim antioksidan menurunkan radikal $\alpha$ tocopherol, dan menghambat oksidase. Flavonoid yang terdapat dalam buah naga merah inilah yang berperan menurunkan kadar glukosa darah tikus dengan diabetes (Sarian et al, 2017 ; Lenny, 2006). Flavonoid menstimulir pemanfaatan glukosa perifer, dengan cara meningkatkan jalur glikolitik dan glikogenik, yang secara simultan menekan jalur glikogenolisis dan glukoneogenesis. Melalui mekanisme seperti tersebut diatas flavonoid dalam buah naga merah memungkinkan dapat mengendalikan glukosa darah, sehingga kadar glukosa darah tikus diabetes menurun (Halliwell and Gutteridge, 2012 ; Middleton, 2000). Hasil pengamatan yang dilakukan berdasarkan uji Post-Hoc Tukey menunjukkan bahwa terdapat perbedaan yang bermakna rata-rata gula darah antar kelompok perlakuan KE yaitu kelompok perlakuan induksi aloksan + jus buah naga dosis III (8 gr/2,5ml 1 kali sehari) dengan kelompok tikus normal (KA), kelompok tikus diabetes (KB), kelompok tikus KC dan kelompok tikus KD, terbukti dengan signifikansi $<0,05$. Nilai rata-rata gula darah tikus kelompok KE lebih kecil dari pada kelompok tikus diabetes (KB), kelompok KC dan kelompok KD, sehingga kelompok KE dengan dosis III (8 gr/2,5 ml) lebih dianjurkan sebagai dosis pilihan terbaik untuk menurunkan kadar gula darah pada tikus wistar karena mampu menurunkan kadar gula darah rerata hingga $\leq 250 \mathrm{mg} / \mathrm{dl}$ dan paling mendekati kadar gula darah kelompok tikus normal (KA).

Pengaruh pemberian jus buah naga merah terhadap perbaikan histopatologis organ otak tikus.

Nekrosis dapat dikenali karena sel atau jaringan menunjukkan perubahan- 
Potensi Jus Buah Naga Merah (Hylocereus polyrhizus) terhadap Perbaikan Jaringan Organ...

I Gede Gelgel Bayu Surya Putra, Dorta Simamora

perubahan tertentu baik secara makroskopis maupun mikroskopis. Faktor pemicu nekrosis dapat berupa iskemia, agen biologik, agen fisik, agen kimia dan juga hipersensitivitas (kerentanan). Agen kimia dalam penelitian ini adalah aloksan, aloksan meningkatkan glukosa darah sehingga menghasilkan kondisi diabetes pada tikus. Glukosa merupakan zat kimia yang berada dalam tubuh, namun ketika konsentrasinya tinggi dapat menimbulkan nekrosis akibat gangguan keseimbangan osmotik sel (Pringgoutomo, 2002). Perubahan yang mencolok terutama terlihat pada jaringan otak kelompok tikus diabetes (KB) yaitu inti sel yang mengalami piknosis, karioreksis, serta kariolisis. Apabila dalam sediaan histologis tampak gambaran inti piknosis, karioreksis dan kariolisis, maka sel tersebut dikatakan mengalami nekrosis (Cheville, 2006). Pada jaringan otak tikus normal (KA) terlihat adanya nekrosis, tetapi masih dalam jumlah yang sedikit. Kematian sel pada jaringan otak tikus normal (KA) merupakan mekanisme yang sudah terprogram dimana setelah mencapai masa hidup tertentu maka sel akan mati. Mekanisme ini disebut apoptosis, yaitu suatu komponen yang normal terjadi dalam perkembangan sel untuk menjaga keseimbangan pada organisme multiseluler. Sel-sel yang mati adalah sebagai respon dari beragam stimulus dan selama apoptosis kematian sel-sel tersebut terjadi secara terkontrol dalam suatu regulasi yang teratur (Jing et al, 2013). Hasil pengamatan histopatologis menunjukkan adanya nekrosis pada jaringan organ otak tikus. Jumlah nekrosis paling tinggi terjadi pada kelompok tikus diabetes (KB) dengan rata-rata 27,6 sel, sedangkan jumlah nekrosis paling sedikit terjadi pada kelompok tikus normal (KA) dengan rata-rata 4,4 sel. Jumlah rata-rata nekrosis pada kelompok perlakuan KC 21,4 sel. Rata-rata nekrosis kelompok perlakuan KD 18 sel, sedangkan jumlah rata-rata nekrosis pada kelompok perlakuan KE lebih sedikit yaitu 10,2 sel. Jumlah rata-rata nekrosis pada KE paling mendekati kelompok tikus normal (KA). Peningkatan jumlah sel yang mengalami nekrosa pada kondisi hiperglikemia disebabkan peningkatan glukoneogenesis. $\mathrm{Hal}$ ini sebagai akibat sel tidak dapat menggunakan glukosa (Fouad 2007). Menurut Halliwell (2012) radikal bebas secara normal diproduksi sebagai hasil metabolisme tubuh (seperti oksidasi adrenalin, dopamine, dan tetrahidrofolat) dan berbagai reaksi pertahanan tubuh (fagositosis oleh makrofag dan monosit), namun pada kondisi hiperglikemia terjadi peningkatan produksi radikal bebas karena peningkatan proses pemecahan lemak (glukoneogenesis), sehingga menyebabkan 
ISSN 1978-2071 (Print); ISSN 2580-5967 (Online) Jurnal IImiah Kedokteran Wijaya Kusuma 8(2) : 84-95, September 2019

terjadinya kondisi oxidative stress, yaitu kondisi dimana kadar radikal bebas lebih tinggi dibandingkan kadar antioksidan endogenous (Fouad 2007 ). Apabila radikal bebas menyerang membran sel (lipoprotein) akan menyebabkan terjadinya reaksi berantai lipid peroksidasi (Halliwell B and Gutteridge, 2012 ; Fouad, 2007)

Kondisi hiperglikemia juga dapat menyebabkan terjadinya atherosklerosis yang kemudian akan mengarah oxidative damage, yaitu perusakan jaringan oleh biomolekul oksigen reaktif (Halliwell 2002). Kondisi atherosklerosis juga menyebabkan iskhemia pada jaringan atau organ yang mendapatkan suplai. Kondisi-kondisi tersebut menyebabkan terjadinya kerusakan jaringan atau organ secara umum pada kondisi hiperglikemia, terutama jaringan atau organ yang memiliki kandungan lemak tinggi sebab lemak sangat rentan terhadap serangan radikal bebas dibandingkan jaringan lain dalam tubuh (Ghorbani, 2017; Fouad 2007). Sifat farmakologis terbaik dari flavonoid adalah kemampuannya untuk bertindak sebagai antioksidan kuat yang telah dilaporkan memainkan peran penting dalam penurunan diabetes mellitus. Sifat biokimia flavonoid tergantung pada struktur, namun, mereka belum dipahami secara menyeluruh. Oleh karena itu, tujuan utama dari penelitian ini adalah untuk menyelidiki sifat antioksidan dan antidiabetik dari beberapa flavonoid yang terkait secara struktural untuk mengidentifikasi posisi kunci yang bertanggung jawab, korelasinya, dan pengaruh metilasi dan asetilasi pada sifat yang sama. Otak merupakan salah satu organ dengan kandungan lemak sangat tinggi $( \pm 80 \%)$ sehingga otak sangat rentan terhadap serangan radikal bebas. Hal ini menyebabkan terjadinya peningkatan kejadian nekrosa neuron piramidal pada kelompok diabetik. Namun peningkatan kejadian nekrosa pada kelompok diabetik mungkin juga disebabkan komplikasi akibat kondisi hiperglikemia. Kondisi hiperglikemia yang berlangsung dalam waktu lama akan menyebabkan kematian sel akibat kekurangan nutrisi (Ghorbani, 2017). Hasil pengujian one way anova nekrosis menunjukkan bahwa pemberian jus buah naga merah berpengaruh terhadap jaringan otak tikus diabetes yang diinduksi aloksan, terbukti dengan signifikansi $p$-value $=0.000$ yaitu $<\alpha(0.05)$. Penurunan jumlah sel yang mengalami nekrosa disebabkan efek kandungan flavonoid dalam buah naga merah yang berperan sebagai antioksidan dan berfungsi menetralisir radikal bebas sehingga meminimalkan efek kerusakan pada sel dan jaringan tubuh (Hui Xu et al, 2018). Antioksidan adalah senyawa yang 
Potensi Jus Buah Naga Merah (Hylocereus polyrhizus) terhadap Perbaikan Jaringan Organ...

I Gede Gelgel Bayu Surya Putra, Dorta Simamora

dapat memberikan elektron ke radikal bebas yang sangat reaktif untuk menunda terjadinya oksidasi lipid. Antioksidan sangat penting bagi tubuh untuk menjaga keseimbangan oksidan dalam tubuh. Sarian et al, 2017 ; Jaafar et al, 2009). Flavonoid memberikan efek neuroprotektif pada otak, termasuk potensi untuk melindungi neuron terhadap cedera yang disebabkan oleh neurotoksin, sebuah kemampuan untuk menekan peradangan saraf, dan potensi untuk meningkatkan daya ingat, belajar dan fungsi kognitif. Efek ini didukung oleh dua proses umum. Pertama, flavonoid berinteraksi dengan protein dan lipid kinase di otak yang menyebabkan penghambatan apoptosis yang dipicu oleh spesies neurotoksik serta meningkatkan hidup neuronal. Kedua, flavonoid memberikan efek menguntungkan pada pembuluh darah serebrovaskular yang menyebabkan angiogenesis, neurogenesis dan perubahan morfologi neuronal. Melalui mekanisme ini, mengonsumsi makanan kaya flavonoid sepanjang hidup berpotensi untuk membatasi atau mencegah neurodegeneration (David et al, 2008 ; Panche et al, 2016)

\section{KESIMPULAN}

Hasil penelitian menunjukkan bahwa pemberian jus buah naga merah terbaik terhadap penurunan kadar gula darah tikus dan jaringan otak tikus yang mengalami nekrosis terdapat pada kelompok KE. Tikus diabetes yang diinduksi aloksan diterapi dengan jus buah naga merah dosis III (8 $\mathrm{gr} / 2,5 \mathrm{ml}$ ). Hal ini menunjukkan bahwa pemberian jus buah naga merah dapat memperbaiki jaringan otak tikus diabetes dari nekrosis secara signifikan dengan $p$ value $=0.000(\alpha<0.05)$.

\section{DAFTAR PUSTAKA}

American Diabetes Association, 2018. Diabetes Care Volume 37 Supplement 1.Diagnosis and Classification of Diabetes Mellitus. S81 - S90.

Biessels GJ and Reijmer YD, 2014. Brain Changers Underlying Cognitive Dysfuction in Diabetes: What can we learn from MRI. Diabetes, 63(7):2244-2252

Cheville, N. F. 2006. Introduction to Veterinary Pathology, 3rd Ed. Blackwell Publishing. USA.

Diabetes Care. 2018. Standard of Medical Care in Diabetes 2018. VOLUME 41 | SUPPLEMENT 1

David Vauzour, Katerina Vafeiadou, Ana Rodriguez-Mateos, Catarina Rendeiro, Jeremy P. E. Spencer. 2008. The neuroprotective potential of flavonoids: a multiplicity of effects. Molecular 
ISSN 1978-2071 (Print); ISSN 2580-5967 (Online) Jurnal IImiah Kedokteran Wijaya Kusuma 8(2) : 84-95, September 2019

Nutrition Group, School of Chemistry, Food and Pharmacy, University of Reading. UK. Pages: 115-126 Elmore

Feranose, Panjuantiningrum. 2009. Pengaruh pemberian buah naga merah (Hylocereus polyrhizus) terhadap kadar glukosa darah Tikus putih yang diinduksi aloksan. UNS Repository.

Fouad T. 2007. Free Radical Source, Type, and Damaging Reaction.

Ghorbani A. Pharmacological properties of Salvia officinalis and its components. Journal of Traditional and Complementary Medicine 7(4) · January 2017

Halliwell B. 2002. Vitamin E and The Treatment and Prevention of Diabetes Mellitus: A Case for Clinical Control. Singapore Medical Journal. Vol 43(9): 479484.

Halliwell B and Gutteridge JMC. 2012. Free radical in Biology and medicine. 4th ed. Oxford University Press

Huang Dezian. Dietary Antioxidants and Health Promotion. Antioxidants $2018: 7$ (9) $1-3$

Hui Xu, Jia Luo, Jia Huang, and Qian Wen. Flavonoids intake and risk of type 2 diabetes mellitus A metaanalysis of prospective cohort studies. Medicine (Baltimore). 2018 May; 97(19): e0686.

Infodatin. 2018. Situasi dan Analisis Diabetes.

http://www.depkes.go.id/resourc es/download/pusdatin/infodatin/ hari-diabetes-sedunia-2018.pdf Jing Hong, Kuan-Hsing Chen, Pei-Ching Kuo, Chia-Chi Pao, Jan-Kan Chen Neurodegeneration in StreptozotocinInduced Diabetic Rats Is Attenuated by Treatment with Resveratrol. Neuroendocrinology 2013;98:116-127

Jaafar R., Rahman ARBB, , Mahmod NZC, and Vasudevan R. 2009. American Journal of Applied Sciences 6. Proximate Analysis of Dragon Fruit (Hylecereus polyhizus). 1341 $-1346$.

Heim KE, Tagliaferro AR, and Bobilya DH, 2002. Flavonoid antioxidants: chemistry, metabolism, and structure-activity relationships. J Nutr Biochem. 13(10):572-584.

Kementerian Kesehatan RI. Sekretariat Jenderal. 2014. Profil Kesehatan Indonesia Tahun 2013. Jakarta : Kementerian Kesehatan RI. 166 167.

Kristanto, D. 2008. Buah Naga Pembudidayaan di Pot dan di 
Potensi Jus Buah Naga Merah (Hylocereus polyrhizus) terhadap Perbaikan Jaringan Organ...

I Gede Gelgel Bayu Surya Putra, Dorta Simamora

Kebun. Penebar Swadaya. Jakarta.

Lenny Sovia. 2006. Senyawa Flavonoida, Fenilpropanoida, dan Alkaloida. USU Repository.

Middleton, E.Jr., Kandaswami, C. dan Theoharides, T.C. (2000). The effects of plant flavonoids on mammalian cells: implications for inflammation, heart disease, and cancer. Pharmacological Reviews 52: 673-751.

Panche A. N. Diwan A. D. and Chandra $\underline{\text {. }}$ R. 2016. Flavonoids: an overview. Journal of Nutritional Science.

https://doi.org/10.1017/jns.2016. 41

Pringgoutomo, S.; S. Himawan; A. Tjarta. 2002. Buku Ajar Patologi I. Jakarta: Sagung Seto.
Sarian MN, Ahmed AQ Ahmed, So'ad SJM, Alhassan AM, Murugesu S, Perumal V, Mohamad SNAS, Khatib A, Latip J. 2017. Antioxidant and Antidiabetic Effects of Flavonoids: A StructureActivity Relationship Based Study. Hindawi BioMed Research International : Vol 2017, 1-14

Szkudelski. T. 2001. Department of Animal Physiology and Biochemistry, University of Agriculture, Poznan, Poland. The Mechanism of Alloxan and Streptozotocin Action in B Cells of the Rat Pancreas. 536 - 546. Utami P. 2003. Tanaman Obat untuk Mengatasi Diabetes Mellitus. Jakarta: Agromedia Pustaka. 